\title{
Review of Dichelachne (Gramineae) in Australia
}

\author{
S.W.L. Jacobs, K.L. McClay and B.K. Simon
}

\begin{abstract}
Jacobs, S.W.L. ${ }^{1}$, McClay, K.L. ${ }^{1}$ \& Simon, B.K. ${ }^{2}{ }^{1}$ National Herbarium of New South Wales, Royal Botanic Gardens, Sydney, N.S.W., Australia, 2000; ${ }^{2}$ Queensland Herbarium, Meiers Rd., Indooroopilly, Queensland, Australia, 4068) 1993. Notes on Dichelachne (Gramineae) in Australia. Telopea 5(2): 325-328. Dichelachne in Australia is assessed. Seven species are recognised and a key provided. The type of $D$. parza is a mixed collection; the name is lectotypified and the species redefined. The relationships between the species are discussed.
\end{abstract}

\section{Introduction}

Veldkamp (1974) revised Dichelachne, recognising three species, D. crinita, $D$. micrantha and D. rara with two subspecies in D. rara; all taxa growing in Australia. Edgar and Connor (1982) realised that Veldkamp's treatment did not adequately reflect the situation in New Zealand, and in their treatment recognised five species viz., D. crinita, D. micrantha, D. sieberiana, $D$. rara and D. inaequiglumis. Although these five species also grow and can be distinguished in Australia, they did not represent all the variation present here (Connor, pers. comm.) resulting in a large residue of specimens that made treatments difficult. So the old treatment lingered on and there has been an unfortunate delay in incorporating the results of the New Zealand study into the Australian grass literature. Simon (1982) described a further species, D. parva and also was the first to include the five species recognised in New Zealand in a key to Australian grasses (Simon, 1990). Morris (1991) recognised four species in Tasmania, including $D$. sieberiana in $D$. rara. $D$. hirtella is the most recent addition, described from northern Victoria and southern New South Wales by Walsh (1992).

While preparing the Dichelachne treatment (Jacobs \& McClay, in press) for the final volume of the Flora of New South Wales it became clear that we now had enough names to deal sensibly with the variation in Australian Dichelachne. It also became clear that there was a problem with the type, and in the circumscription of $D$. parva but that this could be clarified by lectotypification and redefining the species.

There is still considerable variation within Dichelachne and publication of further taxa is quite probable.

\section{Dichelachne parva B.K. Simon}

\section{(i) Lectotypification}

The type of $D$. parva (Queensland, near Wyberba, Blake 4600, BRI 061721) consists of two depauperate plants. The plant on the right is a small specimen of, but otherwise a good match for, $D$. inaequiglumis (Hack. ex Cheesem.) Edgar \& Connor. The plant on the left represents an apparently endemic Australian species that does not appear 
to have any other name. It is distinguished from all other species of Dichelachne in having smaller lemmas (mostly $<4 \mathrm{~mm}$ ) longer than the lower glume, smaller florets, and in the inflorescence being sparse with fine flexuous branches. This specimen is here designated as the lectotype of $D$. parva.

\section{(ii) Circumscription}

The original description of $D$. parva included information from both specimens on the type sheet. Consequently the description needs emending and a revised description is supplied here.

Tufted perennial to $0.8 \mathrm{~m}$ tall. Culms erect, smooth, glabrous, sometimes scaberulous below node; nodes 4-5, glabrous. Leaves mostly basal; sheath tightly enclosing culm, becoming loose with age, smooth and glabrous or scaberulous; ligule a membranous rim $0.7-1.5 \mathrm{~mm}$ long, obtuse, erose, glabrous, one side usually with an auricular lobe 1.2-2.5 mm long, about twice as long as the ligule; blade flat or inrolled, to $20 \mathrm{~cm}$ long, 1-2.5 mm wide, glabrous, abaxial surface scaberulous, adaxial surface sometimes smooth. Inflorescence paniculate, open, narrow, 5-28 cm long, 1-3 cm wide; branches lax, flexuous; rhachis scaberulous, glabrous. Spikelets 3.5-4 mm long (excluding awn), 0.7-1 mm wide, laterally compressed, floret 1, bisexual; pedicel $0.5-4$ $\mathrm{mm}$ long, scaberulous. Glumes unequal, 1-nerved, keeled, glabrous, smooth, upper margin sometimes membranous, keel scabrous; lower glume lanceolate, acute, 2.3-3.2 $\mathrm{mm}$ long, 80-90\% as long as lemma; upper glume narrowly lanceolate, attenuate, 2.8$4 \mathrm{~mm}$ long, $80-100 \%$ the length of the lemma. Lemma lanceolate, $2.8-4 \mathrm{~mm}$ long (excluding awn), subterminally awned from below a membranous 2-toothed tip, 5nerved, keeled, glabrous except for the callus, scaberulous; membranous tip 0.3-1 $\mathrm{mm}$ long, lateral nerves extending as teeth c. $0.1 \mathrm{~mm}$ long; awn 6.5-12 mm long, scaberulous, slightly twisted, at maturity once-geniculate and more strongly twisted; callus with crinkly hairs $0.2-1.2 \mathrm{~mm}$ long. Palea subequal to lemma, hyaline, 2-nerved, 2-keeled, smooth, glabrous, keels scabrous. Lodicules 2, membranous, linear-lanceolate, c. $0.6 \mathrm{~mm}$ long. Anthers 3, 0.3-0.5 mm long, usually cream, sometimes purplebrown when whole inflorescence purple-tinged. Caryopsis c. $3 \mathrm{~mm}$ long, embryo c. $10 \%$ of embryo length. No obvious rhachilla extension.

Distribution: the Darling Downs district of Queensland, Central Coast, Central and Southern Tablelands and South Western Slopes of New South Wales and across into northern Victoria. Mostly on better soils or in damp spots on sandstone or granite, usually in woodland.

Selected SPECIMENS: QueENSLAND: near Wyberba, Blake 460021 Jan 1933, lectotype (BRI); Girraween National Park (28 $\left.566^{\prime} \mathrm{S}, 151^{\circ} 50^{\prime} \mathrm{E}\right)$ Norris $485 \&$ Jacobs, 4 Feb 1986 (NSW). New SouTH

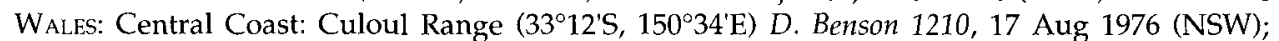
Hornsby, Blakely, Oct 1921 (NSW 7855); Rhodes, Deane, Apr 1887 (NSW 7853); Cheltenham, Vickery, 23 Dec 1947 (NSW 7852). Central Tablelands: Katoomba, Blake 13926, 22 Jan 1939 (BRI, NSW); Blackheath, Vickery, 16 Mar 1935 (NSW). Southern Tablelands: Munderoo State Forest, McBarron 2811, 26 Dec 1948 (NSW). South Western Slopes: 7 km E of Kyeamba, Lloyd s.n. 27 Nov 1980 (NSW). Victoria: Mt Stanley, McBarron 2945, 3 Jan 1949 (NSW).

\section{(iv) Relationships}

Simon (1982) expressed some concern that $D$. parva may be reduced to a variety of $D$. rara after further study, but later (Simon, 1984) he stated that there was a closer affinity of $D$. parva with $D$. inaequiglumis and $D$. sieberiana when examination of the paper by Edgar and Connor (1982) showed that the name D. rara had been widely misapplied to the two latter species. Our (Jacobs \& McClay, in press) study of the 
specimens for the Flora of New South Wales project indicates that $D$. parva is most closely related to $D$. inaequiglumis but is quite distinct from that species. The distinctions are summarised in the key below.

\section{Key to Australian species of Dichelachne}

1 Awn $25 \mathrm{~mm}$ long or longer; inflorescence dense with the obvious long awns semierect or spreading; usually on sand

D. crinita

1* Awn less than $25 \mathrm{~mm}$ long; inflorescence open or dense, the awns not as obvious; on various soils

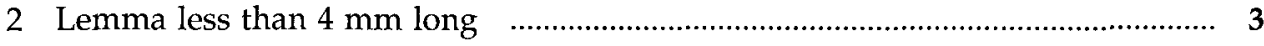

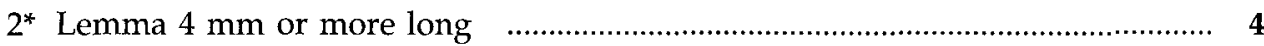

3 Lemma longer than at least the lower glume; inflorescence sparse with flexuous branches

D. parva

$3^{*}$ Lemma shorter than both glumes; inflorescence more or less contracted and the branches not flexuous

D. micrantha

4 Lemma usually $6 \mathrm{~mm}$ or more long, hispid-pubescent; plants often hairy

D. hirtella

$4^{*}$ Lemma mostly less than $6 \mathrm{~mm}$ long, hispid, scabrous or glabrous; plants sometimes hairy (D. sieberiana)

5 Lemma distinctly longer than lower glume, often longer than both glumes D. inaequiglumis

$5^{*}$ Lemma shorter than or subequal to lower glume 6

6 Culms and nodes hairy or scabrous-pubescent; lemma usually scabrous D. sieberiana

6* Culms and nodes glabrous; lemma mostly smooth, sometimes scabrous D. rara

\section{Other species}

As Morris (1991) indicated, D. sieberiana seems most closely allied to $D$. rara. There seems to be more variation in both species in Australia than recorded for New Zealand by Edgar and Connor (1982). The main distinguishing features here seem to be the hairy culms and nodes of $D$. sieberiana. These characters are traditionally viewed with caution in Australia as hairiness has a tendency to increase with increasing dryness and can be environmentally influenced. As well as the hairiness though $D$. sieberiana has lemmas subequal to the lower glume and the lemma surface more or less scabrous. True $D$. rara has glumes with attenuate tips that much exceed the mostly smooth-surfaced lemma, and the nodes (especially) and the culms are 
glabrous. There are some specimens intermediate in some characters with glumes only slightly longer than the lemma and some with slightly scabrous lemmas. We have included these 'intermediate' specimens with $D$. rara here but suspect that further study may uncover further taxa. A species with a contracted inflorescence and an awn less than $10 \mathrm{~mm}$ long from south-eastern Queensland (D. sp. Simon 3221 in Simon 1990) requires further investigation.

$D$. hirtella is part of the $D$. rara $-D$. sieberiana complex, differing from the other two mostly in the larger spikelet parts and larger and denser inflorescence. The lemma surface of $D$. hirtella is more scabrous than in $D$. sieberiana, whereas the lemma surface of $D$. rara is less scabrous again, often smooth. $D$. hirtella frequently (but not always) has hairy culms and nodes similar to $D$. sieberiana, and the relative length of the lemma to the glumes can be similar in both species. The character distribution among these taxa is a bit erratic but the taxa can be sorted without too much difficulty and the resultant classification is an improvement on the previous one.

\section{Acknowledgements}

Many thanks to Liz Norris who helped with field work and in SEM studies, and to Joy Everett for her helpful comments on the manuscript.

\section{References}

Edgar, E. \& Connor, H.E. (1982) Dichelachne (Gramineae) in New Zealand. New Zealand Journal of Botany 20: 303-309.

Jacobs, S.W.L. \& McClay, K.L. (in press) Dichelachne, in Harden, G.J., Flora of New South Wales vol. 4. (New South Wales University Press: Sydney).

Morris, D.I. (1991) The grasses of Tasmania. Tasmanian Herbarium Occasional Publication No. 3.

Simon, B.K. (1982) New species of Gramineae from south-eastern Queensland. Austrobaileya 1: $455-467$.

Simon, B.K. (1984) Corrigenda. Austrobaileya 2: 108.

Simon, B.K. (1990) A key to Australian grasses. Queensland Department of Primary Industries Information Series Q189019.

Veldkamp, J.F. (1974) A taxonomic revision of Dichelachne Endl. (Gramineae) with some new combinations in Stipa L. and Oryzopsis Michx. Blumea 22: 5-12.

Walsh, N.G. (1992) New taxa in Victorian Poaceae (2). Muelleria 7: 451-456.

Manuscript received 28 August 1992

Manuscript accepted 13 January 1993 